\title{
Examination of Strategies Fine Arts High School Students Use during the Practice and Learning of Instrumental Music
}

\author{
Mehtap Aydıner Uygun ${ }^{1}$, Özlem Kılınçer ${ }^{2}$ \\ ${ }^{1}$ Niğde Ömer Halisdemir Üniversitesi Eğitim Fakültesi Güzel Sanatlar Eğitimi Müzik Eğitimi Anabilim Dalı, Turkey \\ ${ }^{2}$ Nevşehir Hacıbektaş Veli Üniversitesi Güzel Sanatlar Fakültesi Müzik ve Sahne Sanatları Bölümü, Turkey \\ Correspondence: Özlem Kılınçer, Nevşehir Hacıbektaş Veli Üniversitesi Güzel Sanatlar Fakültesi Müzik ve Sahne \\ Sanatları Bölümü, Turkey.
}

Received: February 16, 2017

Accepted: March 13, $2017 \quad$ Online Published: March 20, 2017

doi:10.11114/jets.v5i4.2228

URL: https://doi.org/10.11114/jets.v5i4.2228

\begin{abstract}
Like every field of learning, it is important to use various strategies in instrumental music to learn it easily and permanently and to attain the skills to learn independently. This requires determining the strategies used by students studying instrument education. The purpose of this study was to examine the strategies fine arts high school students use during the practice and learning of instrumental music. These strategies are the attention, rehearsal, elaboration, articulation-organization and comprehension monitoring strategies. Students' levels of using practice and learning strategies were examined according to seven variables. The study group consisted of 139 students who were studying at Aksaray, Kayseri, Mersin and Niğde Fine Arts High Schools during the 2015-2016 academic year. The study data was collected using Personal Information Form and Scale for Strategies Used during the Practice and Learning of Instrumental Music. The results showed that students' levels of elaboration strategies were higher than their levels of articulation-organization strategies. It was also determined that students' levels of rehearsal and comprehension monitoring strategies were significantly higher than their levels of other strategies. Furthermore, it was found that students' levels of using practice and learning strategies showed significant differences according to students' experience, instrument practice duration, how they plan their instrument practice duration, from where they learned the strategy, their academic achievement level on the instrument and the factor motivating them to play instrument variables.
\end{abstract}

Keywords: fine arts high school, instrumental music, practice and learning strategies

\section{Introduction}

For students learning to play instrument, the study and learning of instrumental music is like a long enduring journey requiring patience. The students should not lose heart when they face difficulties during this journey, and should be able to continue their journey by always building information and skills on top of the information and skills they learned on their instrument. Reaching the intended destination during the journey can become easier with the appropriate tools the students have in their bags during this journey. These tools are the strategies that will help them overcome the difficulties they face during the journey. Just like in every dimension of learning, the use of various learning strategies is crucial in easily and permanently learning instrumental music and in learners attaining the skill to learn independently. According to Weinstein and Mayer (1986, p. 315), learning strategies are behaviors and thoughts that learners engage in during learning and that are intended to influence the learner's encoding process.

Strategies can change depending on the nature of the task. In this regard, educators have discussed learning strategies by classifying them. Accordingly, learning strategy in each category includes methods that will influence certain aspects of the encoding process to ease one or more types of learning outcomes and performance. When classifications regarding learning strategies are examined, Weinstein and Mayer's (1986) classification stands out as the classification that most recognized and used in many studies (Aicher, 1998; Nielsen, 1999a; Nielsen, 1999b; Nielsen, 2001; Aydıner Uygun \& Kılınçer, 2012a, 2012b; Kılınçer \& Aydıner Uygun, 2013a, 2013b). The present study is based on Weinstein and Mayer's (1986) classification of learning strategies. In addition to this classification, attention strategies, one of the sub-dimensions of learning strategies classification developed by Gagné and Driscoll (1988) are included in the study. Thus, in the current study, the learning strategies are discussed in five groups: attention strategies, rehearsal strategies, 
elaboration strategies, articulation-organization strategies and comprehension monitoring strategies.

When music literature is examined, it is seen that educators and researchers focus on the use of attention, rehearsal, elaboration, articulation-organization and comprehension monitoring strategies as strategies that can be used in the practice and learning of instrumental music. For example, piano educator Pamir (1984) stressed that even the smallest details like ligatures, forzandos, nuances, ornaments, tones, finger numbers and pedal places should not be missed in daily practices. Pamir's suggestions can be associated with attention strategies. Similarly, Fenmen (1997) expressed the necessity of practices like marking the note errors or cadances in the piece, writing the finger numbers that can be easily played on the piece and analysis of the piece in terms of form. Furthermore, he stated that before starting to practice the piece, knowing when the piece was composed, the form of the piece, what kind of difficulties are there in the piece and how the piece show changes in tempo were important for learning and interpreting the piece. Demirova (2008) mentioned that underlining the important parts and using colors or various symbols on the note were effective strategies to draw the attention of the student.

Related to rehearsal strategies, Hallam (1997) recommended regular rehearsals to new instrument students in order to automate the development of their cognitive, auditory and technical skills. Jørgensen (2004) argued that the difficult passages in the piece should be rehearsed until these passages were learned correctly. According to Kochevitsky (1967, p.50), all of the composition should be mentally practiced time to time and Busoni's warning that "if a person is always on piano, he or she will lose the musical meaning" should be kept in mind. According to Maris $(2000$, p.114), rehearsal strategies for musicians are activities that go beyond a repetition of a movement. Rehearsal strategies necessitate concentration, listening carefully and hearing. Related to elaboration strategies, Nielsen (1999b) expressed that new, same and related meters can be distinguished from each other with the analysis of the music material. Related to articulation-organization strategies, Maris (2000) proposed developing verbal and graphic explanations meaningful to the individual while practicing a piece. Again related to articulation-organization strategies, Fenmen (1997) stated that a musician should able to mentally monitor the character changes (laughing, thinking, dreaming, etc.) in the piece that he or she was playing. Related to comprehension monitoring strategies, Geiersbach (2000) put forth that student who practice by organizing and planning learning strategies reached their personal goals in a shorter time. Barry and Hallam (2002) mentioned that practicing piano was effective when the practice was organized and directed towards the goal. Maris (2000) stated the importance of individuals deciding what to do during practice by asking certain questions to themselves.

This music literature data makes students' levels of using practice and learning strategies during instrumental music an interesting topic. When related studies are examined, various studies on musicians' use of practice and learning strategies were found (Akın, 2007; Cangro, 2004; Chung, 2006; Ertem, 2003; Hallam 2001a, 2001b; Hanberry, 2004; Kan \& Kurtuldu, 2012; Kılınçer \& Aydıner Uygun, 2013b; Kurtuldu \& Güçlü, 2010; Leon-Guerrero, 2008; McPherson \& McCormick, 1999; Nielsen 1999a, 1999b, 2001, 2004, 2008; Özer, 2010; Santos \& Gerling, 2011; Schraw, Horn, Thorndike-Christ \& Bruning, 1995; Sikes, 2013; Smith, 2005). Among these studies, Cangro's (2004) study aimed to determine the effect of cooperative learning strategies on musical achievement of beginner instrumental music students. Chung (2006) investigated students' self-regulated learning strategies and examined the relation between these strategies and performance achievement. In a study conducted by Hallam (2001a), relations between students' use of strategies and their professional development in music were examined by taking into account students' individual differences. In another study, Hallam (2001b) focused on strategies and metacognitive strategies musicians used for performance preparations. Hanbery (2004) examined the effects of practice strategies hade on piano teaching in classroom environment. In their study, Kılınçer and Aydıner Uygun (2013b) examined musicians' practice and learning strategies during piano music. In some studies, the effects of rehearsal (Kurtuldu \& Güçlü, 2010), elaboration (Akın, 2007; Özer, 2010) and organization (Ertem, 2003; Kan \& Kurtuldu, 2012) strategies on instrumental music performance were tested. In his study, Leon-Guerrero (2008) aimed to determine the self-regulation strategies used by adolescent instrument player musicians during their practices. In their study, McPherson and McCormick (1999) addressed the possible relationships between the use of cognitive strategies, self-regulation, motivational learning factors and the amount and content of music practice. In many of his studies (1999a, 1999b, 2001, 2004), Nielsen examined musicians' use of strategies. Also, some studies revealed the relationships between musicians' achievement goal orientations and their use of strategies (Nielsen, 2008; Schraw, Horn, Thorndike-Christ \& Bruning, 1995; Smith, 2005). Santos and Gerling (2011) put forth students' diversity of strategies depending on their level of expertise. Sikes (2013) explored the effects of special exercise strategy use on university students playing string instruments.

In the related studies briefly mentioned above, it is seen that the strategies used during the practice and learning of instrumental music were addressed differently depending on the researcher's approach to the subject matter. As a result of the related studies' examination, it is believed that it is necessary to conduct a study focusing on the rehearsal, elaboration, articulation-organization and comprehension monitoring strategies holistically in the field of instrumental music. 


\section{Purpose of the Study}

This study aimed to examine fine arts high school students' levels of using strategies while practicing and learning instrumental music according to seven variables. The variables of the study were determined on the basis of research literature in the field of music. It is believed that exogenous variables such as students' experience, instrument practice duration, how they plan their instrument practice duration, from where they learned the strategy, their academic achievement level on the instrument, their perception of competence level on the instrument and the factor motivating them to play instrument may influence students' levels of using practice and learning strategies. Hence, this study attempted to answer the following research questions:

$>$ Do the fine arts high school students' levels of using strategies while practicing and learning instrumental music differ by:

$\circ$ their experience with the instrument,

$\circ$ their instrument practice duration,

$\circ$ how they plan their instrument practice duration,

$\circ$ from where they learned the strategy,

$\circ$ their academic achievement level on the instrument,

$\circ$ their perceptions of their own competence level on the instrument,

$\circ$ the factor motivating them to play instrument?

\section{Method}

\subsection{Participants}

The scope of this study was limited to students studying in the music department of Turkish fine arts high schools. The reason for selecting fine arts high school students as the study group was the fact that they were at the beginning level of their professional music education process. After they graduate, fine arts high school students go on to study music education for their undergraduate degrees. Therefore, it was believed that findings about instrument teaching during this process would contribute to the music education undergraduate programs. The study group consisted of students going to Aksaray, Kayseri, Mersin and Niğde Fine Arts High Schools. The target population included third- and fourth-year students studying music education in the aforementioned fine arts high schools during the academic year of 2015-2016. $56.1 \%$ of the students were females and $43.9 \%$ were males. While $44.6 \%$ of the students were third-year students, $55.4 \%$ were fourth-year students. While $44.6 \%$ of the students were under the age of $18,55.4 \%$ were above. The students were learning to play bağlama (instrument with three double strings) $(12.9 \%)$, cello $(10.1 \%)$, contrabass $(0.7 \%)$, flute $(10.1 \%)$, guitar $(15.1 \%)$, oud (3.6\%), piano (0.7\%), qanun (5.0\%), violin (33.8\%) and viola (7.9\%).

\subsection{Instrumentation}

Data was collected through the Personal Information Form and the Scale for Strategies Used during the Practice and Learning of Instrumental Music. The Personal Information Form was designed by the researchers to obtain demographic information related to the study. This form was made up of seven demographic questions (students' experience, students' instrument practice duration, how students plan their instrument practice duration, from where students learned the strategy, students' academic achievement level on the instrument, students' perception of competence level on the instrument and the factor motivating students to play instrument). The other data-collection tool used in the study was the Scale for Strategies Used during the Practice and Learning of Instrumental Music. The scale was developed by Aydıner Uygun and Kılınçer (see Appendix A). The scale had 39 items. There were seven items in the attention strategies dimension, five in rehearsal strategies dimension, six in elaboration strategies dimension, seven in articulation-organization strategies dimension and 14 in comprehension monitoring strategies dimension. The factor loading values of the items in the scale ranged from 0.513 to 0.813 . Reliability coefficients for the scale's sub-dimensions were found to be 0.89 for attention strategies dimension, 0.81 for rehearsal strategies dimension, 0.85 for elaboration strategies dimension, 0.87 for articulation-organization strategies dimension and 0.93 for comprehension strategies dimension.

\subsection{Procedure}

The Personal Information Form and the Scale for Strategies Used during the Practice and Learning of Instrumental Music were distributed to the participants. The paper-and-pencil format was used for distributing the questionnaires to the participants. Reproduced by printing, the scale was administered to students in one class hour (45 minutes). The respondents answered some background information about themselves, and had to mention their opinions on their use of practice and learning strategies. The students were asked to mark the most appropriate statement (never, rarely, 
sometimes, frequently, always) with an X. The participants were assumed to reflect their perceptions honestly. For this reason, students' answers to questions in the scale were regarded as truth. In the study, the questionnaires that were not completed and were left blank were excluded from evaluation.

\subsection{Research Design and Data Analysis}

The study employed the survey model, one of the quantitative data-collection methods. In the survey model, there is no attempt to change or affect the subject field of the research (Karasar, 2009). The study tried to clarify the relationship between fine arts high school students' use of practice and learning strategies during instrumental music and the variables of the study's sub-goals. In order to test the differences in practice and learning strategy levels during instrumental music ANOVA was employed in the study for the iterative solutions. Benferroni correction multiple comparison test was performed for the binary comparisons of these levels. Multivariate analysis of variance (MANOVA) was used for the comparison of the five strategy levels (dependent variable) according to independent variables. The interactions of the independent variables were also tested in the MANOVA model. Since the observation numbers of the groups were equal, the Pillai's Trace test results were taken into consideration in MANOVA. Independent t-test and ANOVA were used for the significant differences. After the ANOVA test, Tukey multiple comparison test was used. Assumption of Equality of Covariance Matrices required for the administration of the MANOVA test was examined with Box's Test. While deciding which tests to use, the assumption of normality and the assumption of homogeneity of variance was tested with Kolmogorov-Smirnov and Levene's tests, respectively. In the interpretations, $\alpha=0.01$ and $\alpha=0.05$ levels were taken into account.

\section{Results}

In the current study, Turkish fine arts high school students' levels of using strategies while practicing and learning instrumental music were examined according to seven variables. The study explored whether students' levels of using practice and learning strategies showed significant differences according to students' experience, instrument practice duration, how they plan their instrument practice duration, from where they learned the strategy, their academic achievement level on the instrument, their perception of competence level on the instrument and the factor motivating them to play instrument variables. The results are presented below.

Table 1. Comparison of students' levels of practice and learning strategies during instrumental music

\begin{tabular}{lccrrr}
\hline Strategy & $\mathrm{n}$ & Mean $^{\dagger}$ & SD & Min & Max \\
\hline Attention & 139 & $3.25^{\mathrm{c}}$ & 1.11 & 1.00 & 5.00 \\
Rehearsal & 139 & $4.02^{\mathrm{a}}$ & .91 & 1.00 & 5.00 \\
Elaboration & 139 & $3.60^{\mathrm{b}}$ & .95 & 1.00 & 5.00 \\
Articulation-Organization & 139 & $3.23^{\mathrm{c}}$ & 1.01 & 1.00 & 5.00 \\
Comprehension Monitoring & 139 & $3.85^{\mathrm{a}}$ & .91 & 1.00 & 5.00 \\
\hline
\end{tabular}

${ }^{\ddagger}$ The upper indices next to the mean show the results of the Benferroni correction multiple comparison test.

According to Table 1, there were differences between students' levels of practice and learning strategies during instrumental music $\left(\mathrm{F}_{4,135}=25.43 ; \mathrm{p}<0.01\right)$. As is evident from the results of the multiple comparison test, students' levels of elaboration strategies were significantly higher than their levels of attention and articulation-organization strategies. Furthermore, students' levels of rehearsal and elaboration strategies were found significantly higher than students' levels of other strategies. 
Table 2. MANOVA test

\begin{tabular}{|c|c|c|c|c|c|}
\hline Effect & Value & $\mathrm{F}$ & Hypothesis df & Error df & $\mathrm{p}$ \\
\hline Intercept & .645 & $18.553^{* * *}$ & 5 & 51 & .000 \\
\hline Experience with the instrument & .354 & $2.238^{*}$ & 10 & 104 & .021 \\
\hline Instrument practice duration & .450 & $1.870^{*}$ & 15 & 159 & .030 \\
\hline Planning the instrument practice duration & .465 & $3.148^{* *}$ & 10 & 104 & .001 \\
\hline From where students learned the strategy & .683 & $5.392^{* *}$ & 10 & 104 & .000 \\
\hline Academic achievement level on the instrument & .302 & $4.421^{* *}$ & 5 & 51 & .002 \\
\hline Students' perceptions of their competence level on instrument & .271 & 1.630 & 10 & 104 & .108 \\
\hline Factor motivating students to practice the instrument & .293 & $4.221^{* *}$ & 5 & 51 & .003 \\
\hline Experience $*$ practice duration & 608 & 1.611 & 30 & 275 & .057 \\
\hline Experience $*$ planning practice duration & .517 & 1.604 & 20 & 216 & .053 \\
\hline Experience $*$ from where students learned the strategy & .370 & 1.100 & 20 & 216 & .351 \\
\hline Experience $*$ academic achievement & .184 & 1.055 & 10 & 104 & .404 \\
\hline Experience $*$ perception of competence level & 603 & 1.617 & 20 & 216 & .063 \\
\hline Experience $*$ factor motivating to practice & .241 & 1.140 & 10 & 104 & .128 \\
\hline Practice duration $*$ planning practice duration & 643 & 1.659 & 30 & 275 & .056 \\
\hline Practice duration $*$ from where students learned the strategy & .594 & 1.631 & 30 & 275 & .063 \\
\hline Practice duration $*$ academic achievement & .291 & 1.140 & 15 & 159 & .325 \\
\hline Practice duration * perception of competence level & .641 & 1.595 & 30 & 275 & .059 \\
\hline Practice duration $*$ factor motivating to practice & .294 & 1.118 & 15 & 159 & .362 \\
\hline Planning practice duration $*$ from where students learned the strategy & .329 & .968 & 20 & 216 & .502 \\
\hline Planning practice duration $*$ academic achievement & .094 & 1.063 & 5 & 51 & .392 \\
\hline Planning practice duration $*$ perception of competence level & .287 & 1.123 & 15 & 159 & .340 \\
\hline Planning practice duration $*$ factor motivating to practice & .219 & 1.197 & 10 & 104 & .344 \\
\hline From where students learned the strategy $*$ academic achievement & .205 & 1.190 & 10 & 104 & .306 \\
\hline From where students learned the strategy * perception of competence level & .512 & 2.184 & 15 & 159 & .009 \\
\hline From where students learned the strategy $*$ factor motivating to practice & .300 & 1.833 & 10 & 104 & .064 \\
\hline Academic achievement $*$ perception of competence level & .287 & 1.350 & 10 & 104 & .081 \\
\hline Academic achievement $*$ factor motivating to practice & .134 & 1.584 & 5 & 51 & .181 \\
\hline Perception of competence level $*$ factor motivating to practice & .227 & 1.324 & 10 & 104 & .074 \\
\hline
\end{tabular}

$* p<0.05 ; * * p<0.01$

Table 2's findings showed that interaction effects were insignificant. When the main effects were examined, there was no significant difference between the independent variables according to the perception of competence level on the instrument. However, the other main effects were significant. Findings regarding the univariate analysis for the main effects found significant according to the MANOVA test are presented in the following tables.

Table 3. Comparison of students' levels of practice and learning strategies during instrumental music according to their experience with the instrument

\begin{tabular}{|c|c|c|c|c|c|c|}
\hline Strategy & Experience & $\mathrm{N}$ & Mean $^{\dagger}$ & SD & $\mathrm{F}$ & $\mathrm{P}$ \\
\hline \multirow{3}{*}{ Attention } & $2-3$ years & 50 & $3.09^{\mathrm{a}}$ & 1.10 & \multirow{3}{*}{$3.341^{*}$} & \multirow{3}{*}{0.038} \\
\hline & 4 years & 53 & $3.12^{\mathrm{ab}}$ & 1.15 & & \\
\hline & 5 years or more & 36 & $3.65^{b}$ & .97 & & \\
\hline \multirow{3}{*}{ Rehearsal } & $2-3$ years & 50 & 4.04 & .82 & \multirow{3}{*}{2.424} & \multirow{3}{*}{0.092} \\
\hline & 4 years & 53 & 3.83 & 1.04 & & \\
\hline & 5 years or more & 36 & 4.26 & .78 & & \\
\hline \multirow{3}{*}{ Elaboration } & $2-3$ years & 50 & 3.64 & .94 & \multirow{3}{*}{1.925} & \multirow{3}{*}{0.150} \\
\hline & 4 years & 53 & 3.42 & 1.05 & & \\
\hline & 5 years or more & 36 & 3.81 & .76 & & \\
\hline \multirow{3}{*}{ Articulation-Organization } & $2-3$ years & 50 & 3.27 & 1.04 & \multirow{3}{*}{0.486} & \multirow{3}{*}{0.616} \\
\hline & 4 years & 53 & 3.12 & 1.06 & & \\
\hline & 5 years or more & 36 & 3.32 & .90 & & \\
\hline \multirow{3}{*}{ Comprehension Monitoring } & $2-3$ years & 50 & 3.75 & .94 & \multirow{3}{*}{2.009} & \multirow{3}{*}{0.138} \\
\hline & 4 years & 53 & 3.76 & 1.00 & & \\
\hline & 5 years or more & 36 & 4.11 & .69 & & \\
\hline
\end{tabular}

$* p<0.05^{\dagger}$ The upper indices next to the mean show the results of the Tukey multiple comparison test.

In Table 3, it is evident that students' levels of attention strategy showed differences according to their experience with the instrument $(\mathrm{p}<0.05)$. Based on the findings, it can be said that attention strategy levels of students who had five or more years of experience with the instrument were significantly higher than students who had 2-3 years of experience with the instrument. 
Table 4. Comparison of students' levels of practice and learning strategies during instrumental music according to how much time they spent on practicing

\begin{tabular}{|c|c|c|c|c|c|c|}
\hline Strategy & Duration & $\mathrm{N}$ & Mean $^{\dagger}$ & SD & $\mathrm{F}$ & $\mathrm{P}$ \\
\hline \multirow{4}{*}{ Attention } & Less than 1 hour & 30 & $2.69^{\mathrm{a}}$ & 1.23 & \multirow{4}{*}{$3.474^{*}$} & \multirow{4}{*}{0.018} \\
\hline & $1-3$ hours & 47 & $3.43^{\mathrm{b}}$ & .98 & & \\
\hline & 4-6 hours & 26 & $3.35^{\mathrm{b}}$ & 1.13 & & \\
\hline & More than 6 hours & 36 & $3.40^{\mathrm{b}}$ & 1.05 & & \\
\hline \multirow{4}{*}{ Rehearsal } & Less than 1 hour & 30 & $3.52^{\mathrm{a}}$ & 1.07 & \multirow{4}{*}{$4.287^{* *}$} & \multirow{4}{*}{0.006} \\
\hline & 1-3 hours & 47 & $4.11^{\mathrm{b}}$ & .72 & & \\
\hline & 4-6 hours & 26 & $4.11^{\mathrm{b}}$ & .98 & & \\
\hline & More than 6 hours & 36 & $4.25^{\mathrm{b}}$ & .81 & & \\
\hline \multirow{4}{*}{ Elaboration } & Less than 1 hour & 30 & 3.30 & 1.16 & \multirow{4}{*}{1.516} & \multirow{4}{*}{0.213} \\
\hline & $1-3$ hours & 47 & 3.61 & .93 & & \\
\hline & 4-6 hours & 26 & 3.66 & .84 & & \\
\hline & More than 6 hours & 36 & 3.79 & .83 & & \\
\hline \multirow{4}{*}{ Articulation-Organization } & Less than 1 hour & 30 & $2.74^{\mathrm{a}}$ & 1.09 & \multirow{4}{*}{$3.279^{*}$} & \multirow{4}{*}{0.023} \\
\hline & $1-3$ hours & 47 & $3.43^{\mathrm{b}}$ & .88 & & \\
\hline & 4-6 hours & 26 & $3.37^{\mathrm{b}}$ & .83 & & \\
\hline & More than 6 hours & 36 & $3.26^{\mathrm{b}}$ & 1.12 & & \\
\hline \multirow{4}{*}{ Comprehension monitoring } & Less than 1 hour & 30 & $3.31^{\mathrm{a}}$ & 1.11 & \multirow{4}{*}{$4.874^{* *}$} & \multirow{4}{*}{0.003} \\
\hline & $1-3$ hours & 47 & $3.96^{\mathrm{b}}$ & .73 & & \\
\hline & 4-6 hours & 26 & $4.07^{b}$ & .83 & & \\
\hline & More than 6 hours & 36 & $3.98^{b}$ & .88 & & \\
\hline
\end{tabular}

$* p<0.05 ; * * p<0.01{ }^{\dagger}$ The upper indices next to the mean show the results of the Tukey multiple comparison test.

According to the findings in Table 4, it can be said that attention, rehearsal, articulation-organization and comprehension monitoring strategy levels of students who spent more than one hour practicing on their instruments were significantly higher than students who spent less than one hour practicing on their instruments $(\mathrm{p}<0.05)$.

Table 5. Comparison of students' levels of practice and learning strategies during instrumental music according to how they plan their time spent on practicing their instrument

\begin{tabular}{|c|c|c|c|c|c|c|}
\hline Strategy & $\begin{array}{l}\text { How students plan their time } \\
\text { spent on practicing }\end{array}$ & $\mathrm{N}$ & Mean $^{\dagger}$ & SD & $\mathrm{F}$ & $\mathrm{P}$ \\
\hline \multirow{3}{*}{ Attention } & Everyday & 46 & $3.48^{\mathrm{a}}$ & 1.04 & \multirow{3}{*}{$10.444^{* *}$} & \multirow{3}{*}{0.000} \\
\hline & Free time & 68 & $3.41^{\mathrm{a}}$ & 1.06 & & \\
\hline & Before exam & 25 & $2.39^{\mathrm{b}}$ & .98 & & \\
\hline \multirow{3}{*}{ Rehearsal } & Everyday & 46 & $4.26^{\mathrm{a}}$ & .76 & \multirow{3}{*}{$8.716^{* *}$} & \multirow{3}{*}{0.000} \\
\hline & Free time & 68 & $4.09^{\mathrm{a}}$ & .84 & & \\
\hline & Before exam & 25 & $3.38^{\mathrm{b}}$ & 1.08 & & \\
\hline \multirow{3}{*}{ Elaboration } & Everyday & 46 & $3.85^{\mathrm{a}}$ & .90 & \multirow{3}{*}{$7.738^{* *}$} & \multirow{3}{*}{0.001} \\
\hline & Free time & 68 & $3.65^{\mathrm{a}}$ & .89 & & \\
\hline & Before exam & 25 & $2.98^{b}$ & .97 & & \\
\hline \multirow{3}{*}{ Articulation-Organization } & Everyday & 46 & $3.39^{\mathrm{a}}$ & .95 & \multirow{3}{*}{$15.279^{* *}$} & \multirow{3}{*}{0.000} \\
\hline & Free time & 68 & $3.45^{\mathrm{a}}$ & .90 & & \\
\hline & Before exam & 25 & $2.31^{\mathrm{b}}$ & .91 & & \\
\hline \multirow{3}{*}{ Comprehension monitoring } & Everyday & 46 & $4.15^{\mathrm{a}}$ & .85 & \multirow{3}{*}{$10.252^{* *}$} & \multirow{3}{*}{0.000} \\
\hline & Free time & 68 & $3.88^{\mathrm{a}}$ & .77 & & \\
\hline & Before exam & 25 & $3.19^{b}$ & 1.08 & & \\
\hline
\end{tabular}

** $p<0.01{ }^{\dagger}$ The upper indices next to the mean show the results of the Tukey multiple comparison test.

Table 5 shows that there were differences between students' levels of practice and learning strategies during instrumental music according to how they plan their time spent on practicing their instrument $(p<0.05)$. According to the findings, it can be said that practice and learning strategy levels of students practicing their instrument every day and on their free time were significantly higher than students practicing before their exams. 
Table 6. Comparison of students' levels of practice and learning strategies during instrumental music according to from where they learned the strategy

\begin{tabular}{|c|c|c|c|c|c|c|}
\hline Strategy & $\begin{array}{l}\text { From where students learned the } \\
\text { strategy }\end{array}$ & $\mathrm{n}$ & Mean & SD & $\mathrm{F}$ & $\mathrm{P}$ \\
\hline \multirow{3}{*}{ Attention } & Teacher & 60 & $3.47^{\mathrm{a}}$ & 1.03 & \multirow{3}{*}{$4.184^{*}$} & \multirow{3}{*}{0.017} \\
\hline & Myself or a friend & 22 & $2.69^{b}$ & 1.11 & & \\
\hline & All & 57 & $3.22^{\mathrm{a}}$ & 1.12 & & \\
\hline \multirow{3}{*}{ Rehearsal } & Teacher & 60 & $4.15^{\mathrm{a}}$ & .72 & \multirow{3}{*}{$7.148^{* *}$} & \multirow{3}{*}{0.001} \\
\hline & Myself or a friend & 22 & $3.37^{b}$ & 1.24 & & \\
\hline & All & 57 & $4.12^{\mathrm{a}}$ & .85 & & \\
\hline \multirow{3}{*}{ Elaboration } & Teacher & 60 & $3.70^{\mathrm{a}}$ & .92 & \multirow{3}{*}{$6.010^{* *}$} & \multirow{3}{*}{0.003} \\
\hline & Myself or a friend & 22 & $2.98^{b}$ & 1.06 & & \\
\hline & All & 57 & $3.73^{\mathrm{a}}$ & .85 & & \\
\hline \multirow{3}{*}{ Articulation-Organization } & Teacher & 60 & 3.33 & .95 & \multirow{3}{*}{2.883} & \multirow{3}{*}{0.059} \\
\hline & Myself or a friend & 22 & 2.76 & 1.03 & & \\
\hline & All & 57 & 3.30 & 1.03 & & \\
\hline \multirow{3}{*}{ Comprehension monitoring } & Teacher & 60 & $4.07^{\mathrm{a}}$ & .70 & \multirow{3}{*}{$7.944^{* *}$} & \multirow{3}{*}{0.001} \\
\hline & Myself or a friend & 22 & $3.21^{\mathrm{b}}$ & 1.22 & & \\
\hline & All & 57 & $3.85^{\mathrm{c}}$ & .88 & & \\
\hline
\end{tabular}

$* p<0.05 ; * * p<0.01^{\dagger}$ The upper indices next to the mean show the results of the Turkey multiple comparison test.

In Table 6, it is seen that attention strategy levels of students who learned the strategy by themselves or from their friends were lower than other students $(\mathrm{p}<0.05)$. The same result is also valid for rehearsal and elaboration strategies $(\mathrm{p}<0.01)$. When students' levels of comprehension monitoring strategies were examined, it was seen that comprehension monitoring strategy levels of students who learned the strategy from their teachers were higher than other students $(\mathrm{p}<0.01)$.

Table 7. Comparison of students' levels of practice and learning strategies during instrumental music according to academic achievement on the instrument

\begin{tabular}{|c|c|c|c|c|c|c|}
\hline Strategy & Academic achievement & $\mathrm{N}$ & Mean & SD & $\mathrm{t}$ & $\mathrm{P}$ \\
\hline \multirow{2}{*}{ Attention } & 70-100 Points & 45 & 3.58 & 1.09 & \multirow{2}{*}{$2.506^{*}$} & \multirow{2}{*}{0.013} \\
\hline & 50-70 Points & 94 & 3.09 & 1.09 & & \\
\hline \multirow{2}{*}{ Rehearsal } & 70-100 Points & 45 & 4.46 & .72 & \multirow{2}{*}{$4.222^{* *}$} & \multirow{2}{*}{0.000} \\
\hline & 50-70 Points & 94 & 3.80 & .92 & & \\
\hline \multirow{2}{*}{ Elaboration } & 70-100 Points & 45 & 3.89 & .95 & \multirow{2}{*}{$2.545^{*}$} & \multirow{2}{*}{0.012} \\
\hline & 50-70 Points & 94 & 3.46 & .92 & & \\
\hline \multirow{2}{*}{ Articulation-Organization } & $70-100$ Points & 45 & 3.58 & .99 & \multirow{2}{*}{$2.964^{* *}$} & \multirow{2}{*}{0.004} \\
\hline & 50-70 Points & 94 & 3.06 & .98 & & \\
\hline \multirow{2}{*}{ Comprehension Monitoring } & 70-100 Points & 45 & 4.25 & .65 & \multirow{2}{*}{$3.765^{* * *}$} & \multirow{2}{*}{0.000} \\
\hline & 50-70 Points & 94 & 3.65 & .96 & & \\
\hline
\end{tabular}

$* p<0.05 ; * * p<0.01$

According to findings in Table 7, practice and learning strategy levels of students who scored 70 or more out of 100 were significantly higher than other students.

Table 8. Comparison of students' levels of practice and learning strategies during instrumental music according to the factor motivating them to play instrument

\begin{tabular}{|c|c|c|c|c|c|c|}
\hline Strategy & Factor motivating & $\mathrm{N}$ & Mean & SD & $\mathrm{t}$ & $\mathrm{P}$ \\
\hline \multirow{2}{*}{ Attention } & Want to learn & 86 & 3.38 & 1.09 & \multirow{2}{*}{1.803} & \multirow{2}{*}{0.074} \\
\hline & Other reasons & 53 & 3.03 & 1.11 & & \\
\hline \multirow{2}{*}{ Rehearsal } & Want to learn & 86 & 4.18 & .76 & \multirow{2}{*}{$2.772^{* * *}$} & \multirow{2}{*}{0.006} \\
\hline & Other reasons & 53 & 3.75 & 1.06 & & \\
\hline \multirow{2}{*}{ Elaboration } & Want to learn & 86 & 3.71 & .87 & \multirow{2}{*}{1.737} & \multirow{2}{*}{0.085} \\
\hline & Other reasons & 53 & 3.42 & 1.05 & & \\
\hline \multirow{2}{*}{ Articulation-Organization } & Want to learn & 86 & 3.32 & .99 & \multirow{2}{*}{1.369} & \multirow{2}{*}{0.173} \\
\hline & Other reasons & 53 & 3.08 & 1.04 & & \\
\hline \multirow{2}{*}{ Comprehension monitoring } & Want to learn & 86 & 3.97 & .84 & \multirow{2}{*}{$2.030^{*}$} & \multirow{2}{*}{0.044} \\
\hline & Other reasons & 53 & 3.65 & 1.00 & & \\
\hline
\end{tabular}

$* p<0.05 ; * * p<0.01$

In table 8 , there were differences between students' levels of rehearsal and comprehension monitoring strategies according to the factor motivating them to play instrument $(\mathrm{p}<0.05)$. Based on the findings, it can be said that levels of rehearsal and comprehension monitoring strategies of students practicing their instruments with the want to learn were 
significantly higher than other students.

\section{Discussion and Conclusions}

This study aimed to examine Turkish fine arts high school students' levels of using strategies while practicing and learning instrumental music according to seven variables. At the end of this study, students' levels of elaboration strategies were higher than their levels of attention and articulation-organization strategies. It was also determined that students' levels of rehearsal and comprehension monitoring strategies were significantly higher than their levels of other strategies. The results of this study supports the results of Gruson's study (1988). In his work, it was revealed that single notes or sections during the practice of music pieces were frequently repeated. Hallam (2001a) examined the relationship between students' use of strategies and professional development in the field of instrumental music. In his study, it was determined that participants used rehearsal strategies first. The results also show similarities with Hanberry's study (2004) results. In Hanberry's study (2004), it was found that the subjects spent most of their piano practicing time on rehearsing the pieces and the least of their time on analyzing the notes. In addition, the results of the current study were similar to the results of Kılınçer and Aydıner Uygun's study (2013b). Kılınçer and Aydıner Uygun (2013b) put forth that students used rehearsal and comprehension monitoring strategies first while practicing learning piano music. In her study, Leon-Guerrero (2008) determined that rehearsal strategies were used in most of the reports taken from the students during instrumental practice. As a result of Santos and Gerling's study (2011), it was revealed that rehearsal strategies were included in every student's piano practice routine regardless of their level of expertise. In Kurtuldu's study (2007a), creating visual images (equivalent to the articulation strategy in this study) in piano education was found to be the least used strategy. This result is consistent with the fact that level of articulation-organization strategies was found lower than the levels of other strategies in this study. The current study's result regarding the use of attention strategies is similar to the result of Kurtuldu's study (2007b). Kurtuldu (2007b) determined that students used the "attention" strategies at the lowest level while practicing piano music. Similarly, Yokuş (2010) put forth that music teacher candidates used "attention" strategies at the medium level while learning piano music.

Levels of Practice and Learning Strategies According to Students' Experience with the Instrument

According to the results of this study, attention strategy levels of students who had five or more years of experience with the instrument were significantly higher than students who had 2-3 years of experience with the instrument. Unlike the present study, Hallam (2001b) determined that professional musicians exhibited a wide range of "metacognitive" behaviors (equivalent to the comprehension monitoring strategy in this study) during performance preparations covering technical and interpretation issues and during learning related problems like concentration, planning, control and evaluation.

Levels of Practice and Learning Strategies According to How Much Students Spent on Practicing

According to the findings of this study, attention, rehearsal, articulation-organization and comprehension monitoring strategy levels of students who spent more than one hour practicing on their instruments were significantly higher than students who spent less than one hour practicing on their instruments. Similarly, in their study where Aydıner Uygun and K1lınçer (2012b) examined the use of learning strategies in piano music education determined that as the duration of students' piano practice increased, their levels of using learning strategies increased. The results of the current study also support the results of McPherson and McCormick's study. McPherson and McCormick (1999) established that piano students who practiced long hours tended to mentally rehearse the pieces they were working on. They, also, stated that students who spent a lot of time practicing were more competent in playing pieces that require more practice time, identifying the difficult parts of a piece and organizing their practice process with strategies that ensures effective learning.

Levels of Practice and Learning Strategies According to how Students Plan Their Time Spent on Practicing Their Instrument

According to the findings, practice and learning strategy levels of students who practice their instrument every day and on their free time were found significantly higher than students who practice before their exams. This result is consistent with the result of Kılınçer and Aydıner Uygun's study (2013b). They also determined that practice and learning strategy levels of students who practice piano regularly were high.

Levels of Practice and Learning Strategies According to from Where Students Learned the Strategy

According to the study findings, attention, rehearsal, elaboration and comprehension monitoring strategy levels of students who learned the strategies from their teachers were higher than other students. These results are similar to Aydıner Uygun and Kılınçer's study (2012b). They also determined that strategy levels of students who learned the strategies they used while practicing and learning piano from their teachers were higher than other students. 
Levels of Practice and Learning Strategies According to Academic Achievement on the Instrument

According to study findings, practice and learning strategy levels of students who scored 70 or more out of 100 were significantly higher than other students. Similar to the findings of the current study, some studies also found positive relationships between the use of more than one learning strategy and academic achievement level (Aydiner Uygun \& Kılınçer, 2012a, Kılınçer \& Aydıner Uygun, 2013b; Yokuş, 2009). The results of this study also support the results obtained from Cangro's study (2004). In his study, Cangro put forth that successful students used cooperative learning strategies more and music performance of these students were higher. Similarly, Chung (2006) revealed that students with high achievement scores used strategies more and there was a significant difference in the use of strategies between the students in the upper achievement group and students in the lower achievement group. In related studies, significant relationship between the use of rehearsal (Kurtuldu \& Güçlü, 2010), elaboration (Akın, 2007; Özer, 2010) and organization (Ertem, 2003; Kan \& Kurtuldu, 2012) strategies and increase in students' achievement level were found. Nielsen (1999a) revealed that advanced org students used more alternative practices and learning strategies. This result is consistent with the current study's result that argued successful students used more strategies. As a result of Sikes's study (2013), it was seen that each learning strategy significantly improved university students playing string instruments.

Levels of Practice and Learning Strategies According to the Factor Motivating Students to Play Instrument

According to the present study's results, levels of rehearsal and comprehension monitoring strategies of students who practice their instruments with the want to learn were significantly higher than other students. Similar to this study, in his study, Nielsen (2008) determined that students who said they used learning strategies more had a tendency for learning. The results of this study is similar to the study results of Schraw, Horn, Thorndike-Christ and Bruning (1995). They put forth that students who scored high on the learning orientation dimension used more strategies and had more metacognitive knowledge about cognitive processes. The study results also support the results of Smith's (2005) study. Smith expressed that learning orientation levels of students who indicated using more learning strategies were higher.

\section{Recommendations}

Based on the results of this study, it is believed that teaching students strategies they can use during the practice and learning of instrumental music will have positive effects on their academic achievement level. In the current study, it was found that students who indicated their teachers as their strategy resource and regularly practiced had high levels of using practice and learning strategies. This places important responsibilities on the instrument teachers in teaching students the habit of regularly practicing and guiding students to use learning strategies. Teachers may be encouraged to attend meetings like seminars and symposiums so they can guide their students in the teaching of learning strategies. Researchers can examine students' levels of using learning strategies in individual and collective voice training, music theory, music history and so on. Researchers can also determine the effects of strategies that can be used in the practice and learning of instrumental music on instrument performance. Furthermore, the relationships between the strategies students use during the practice and learning of instrumental music and variables like learning style, learning approach and achievement goal orientation can be examined.

\section{References}

Aicher, C. A. O. (1998). Strategies for learning piano repertoire: Learning as a process. Doctoral dissertation, Columbia University Teachers College, AAT 9839045.

Akın, Ö. (2007). The use of elaboration strategy and its efficiency level in violin lessons given in music departments of anatolian fine arts high schools. Doctoral dissertation, Gazi University, Ankara, Turkey. Retrieved from https://tez.yok.gov.tr/UlusalTezMerkezi

Aydıner, U. M., \& Kılınçer, Ö. (2012a). Evaluation of the relationship between the levels of achievement and the levels of learning strategy utilisation: The fine arts and sports colleges case. e-Journal of New World Sciences Academy, $7(2), 199-213$.

Aydıner, U. M., \& Kılınçer, Ö. (2012b). Examining the levels of using the learning strategies for learning the piano repertoire according to some variables: Sample of fine arts and sports high schools. International Journal of Human Sciences, 9(1), 965-992.

Barry, N. H., \& Hallam, S. (2002). Practice. In R. Parncutt \& G. E. McPherson, (Eds.), The science and psychology of music performance (pp. 151-165). Oxford, UK: Oxford University Press. https://doi.org/10.1093/acprof:oso/9780195138108.003.0010

Cangro R. M. (2004). The effects of cooperative learning strategies on the music achievement of beginning instrumentalists. Doctoral dissertation, Available from ProQuest Dissertations and Theses database, UMI No. 
3139428.

Chung, J. W. (2006). Self-regulated learning in piano practice of middle school piano majors in Korea. Doctoral dissertation, Columbia University.

Demirova, G. (2008). The impact of piano education on students' concentration skills. Doctoral dissertation, Ankara University, Ankara, Turkey. Retrieved from https://tez.yok.gov.tr/UlusalTezMerkezi

Ertem, Ş. (2003). States of learning strategies being used and efficacy level of organizational strategy on fundamental piano education at the music department of Ankara Anatolian Fine-Arts High School. Doctoral dissertation, Gazi University, Ankara, Turkey. Retrieved from https://tez.yok.gov.tr/UlusalTezMerkezi

Fenmen, M. (1997). Müzikçinin El Kitabı [Your Musician's Manual]. Ankara: Music Encyclopedia Publications.

Gagné, R. M., \& Driscoll, M. P. (1988). Essentials of learning for instruction. (2nd ed.). Englewood Clilffs, NJ: Prentice-Hall.

Geiersbach, F. J. (2000). Musical thinking in instrumental practice: An investigation of practice strategies used by experienced musicians. Dissertation Abstracts International, 61(6), AAT. UMI No. 9976723.

Gruson, L. M. (1988). Rehearsal skill and musical competence: Does practice make perfect? In Sloboda J. A. (Ed.), Generative Processes in Music: The Psychology of Performance Improvisation and Composition. London: Oxford University Press.

Hallam, S. (1997). What do we know about practising? Towards a model synthesising the research literature. In Jørgensen H. \& Lehmann A. (Eds.), Does practice make perfect? Current theory and research on instrumental music practice (pp. 179-231). Oslo, Norway: Norges musikkhgskole.

Hallam, S. (2001a). The development of expertise in young musicians: Strategy use, knowledge acquisition and individual diversity. Music Education Research, 3(1), 7-23. https://doi.org/10.1080/14613800020029914

Hallam, S. (2001b). The development of meta-cognition in musicians: Implications for education. The British Journal of Music Education, 18(1), 27-39. https://doi.org/10.1017/S0265051701000122

Hanberry, M. A. (2004). Effects of practice strategies, metronome use, meter, hand, and musical function on dual-staved piano performance accuracy and practice time usage of undergraduate non-keyboard music majors. Doctoral dissertation, UMI No. 3136174.

Jørgensen, H. (2004). Strategies for individual practice. In Williamon A. (Ed.), Musical excellence: Strategies and techniques to enhance performance (pp. 85-103). New York, NY: Oxford University Press.

Kan, A., \& Kurtuldu, M. K. (2012). Effects of planned organizational strategies in piano training on student success. $X$. Ulusal Müzik Eğitimi Sempozyumu, Proceedings Book (pp. 458-464). Niğde University Publications, No. 26.

Karasar, N. (2009). Scientific Research Method (19th Edition). Ankara: Nobel Publishing.

Kilınçer, Ö., \& Aydıner Uygun, M. (2013a). The development scale of learning strategies used in piano lesson. International Journal of Human Sciences, 10(1), 468-493.

Kılınçer, Ö., \& Aydıner Uygun, M. (2013b). Analysing the level of learning strategies which music teacher candidates use in piano lessons. e-Journal of New World Sciences Academy, 8(2), 206-237.

Kochevitsky, G. A. (1967). The Art of Piano Playing: A Scientific Approach. Summy-Birchard Inc.

Kurtuldu, M. K. (2007a). Status of current learning strategies and utility of visual images strategy in piano education based on information processing theory. Doctoral dissertation, Gazi University, Ankara, Turkey. Retrieved from https://tez.yok.gov.tr/UlusalTezMerkezi

Kurtuldu, M. K. (2007b). The use of piano practice methods by piano students. Milli Ĕgitim Dergisi, 176, 1-15.

Kurtuldu, M. K., \& Güçlü, H. E. (2010). Effects of planned and equally repeated practice in piano training on student success. Elektronik Sosyal Bilimler Dergisi, 9(34), 196-204.

Leon-Guerrero, A. (2008). Self-regulation strategies used by student musicians during music practice. Music Education Research, 10 (1), 91-106. https://doi.org/10.1080/14613800701871439

Maris, B. E. (2000). Making Music at the Piano: Learning Strategies for Adult Students. New York: Oxford University Press.

McPherson, G. E., \& McCormick, J. (1999). Motivational and self-regulated learning components of musical practice. Bulletin of the Council for Research in Music Education, 141, 98-102. 
Nielsen, S. G. (1999a). Learning strategies in instrumental music practice. British Journal of Music Education, 16(3), 275-291. https://doi.org/10.1017/S0265051799000364

Nielsen, S. G. (1999b). Regulation of learning strategies during practice. Psychology of Music, 27(2), 218-229. https://doi.org/10.1177/0305735699272015

Nielsen, S. G. (2001). Self-regulating learning strategies in instrumental music practice. Music Education Research, 3(2), 155-167. https://doi.org/10.1080/14613800120089223

Nielsen, S. G. (2004). Strategies and self-efficacy beliefs in instrumental and vocal individual practice: A study of students in higher music education. Psychology of Music, 32(4), 418-431. https://doi.org/10.1177/0305735604046099

Nielsen, S. G. (2008). Achievement goals, learning strategies and instrumental performance. Music Education Research, 10(2), 235-247. https://doi.org/10.1080/14613800802079106

Özer, Z. (2010). The effect of elaboration strategies used in the piano course of Bursa Zeki Müren Fine Arts and Sports High School's Music Department on students' learning levels and attitudes. Master dissertation, Balikesir University, Balıkesir, Turkey. Retrieved from https://tez.yok.gov.tr/UlusalTezMerkezi

Pamir, L. (1984). Contemporary Piano Education. İstanbul: Beyaz Köşk Music Publications.

Santos, R. A. T., \& Gerling, C. C. (2011). Piano repertoire preparation from a praxial perspective. International Symposium on Performance Science, 342-346.

Schraw, G., Horn, C., Thorndike-Christ, T., \& Bruning, R. (1995). Academic goal orientations and student classroom achievement. Contemporary Educational Psychology, 20(3), 359-368. https://doi.org/10.1006/ceps.1995.1023

Sikes, P. L. (2013). The effects of specific practice strategy use on university string players' performance. Journal of Research in Music Education, 61(3), 318-333. https://doi.org/10.1177/0022429413497225

Smith, B. P. (2005). Goal orientation, implicit theory of ability and collegiate instrumental music practice. Psychology of Music, 33(1), 36-57. https://doi.org/10.1177/0305735605048013

Weinstein, C. E., \& Mayer, R. E. (1986). The teaching of learning strategies. In M. C. Wittock (Ed.), Handbook of Research on Teaching (pp. 315-327). New York: Maccmillan Company.

Yokuş, H. (2009). The effectiveness of utilizing the learning strategies in piano education to performance and metacognitive awareness. Doctoral dissertation, Marmara University, İstanbul, Turkey. Retrieved from https://tez.yok.gov.tr/UlusalTezMerkezi

Yokuş, H. (2010). The investigation of the levels of music teachers' using the learning strategies to learn piano repertoire. International Conference on New Horizons in Education, Proceedings Book (pp. 619-625). Turkish Republic of Northern Cyprus. 


\section{Appendix-A}

Scale for Strategies Used during the Practice and Learning of Instrumental Music (Coding 1: Never, 2: Seldom, 3 : Sometimes, 4: Often, 5: Always)

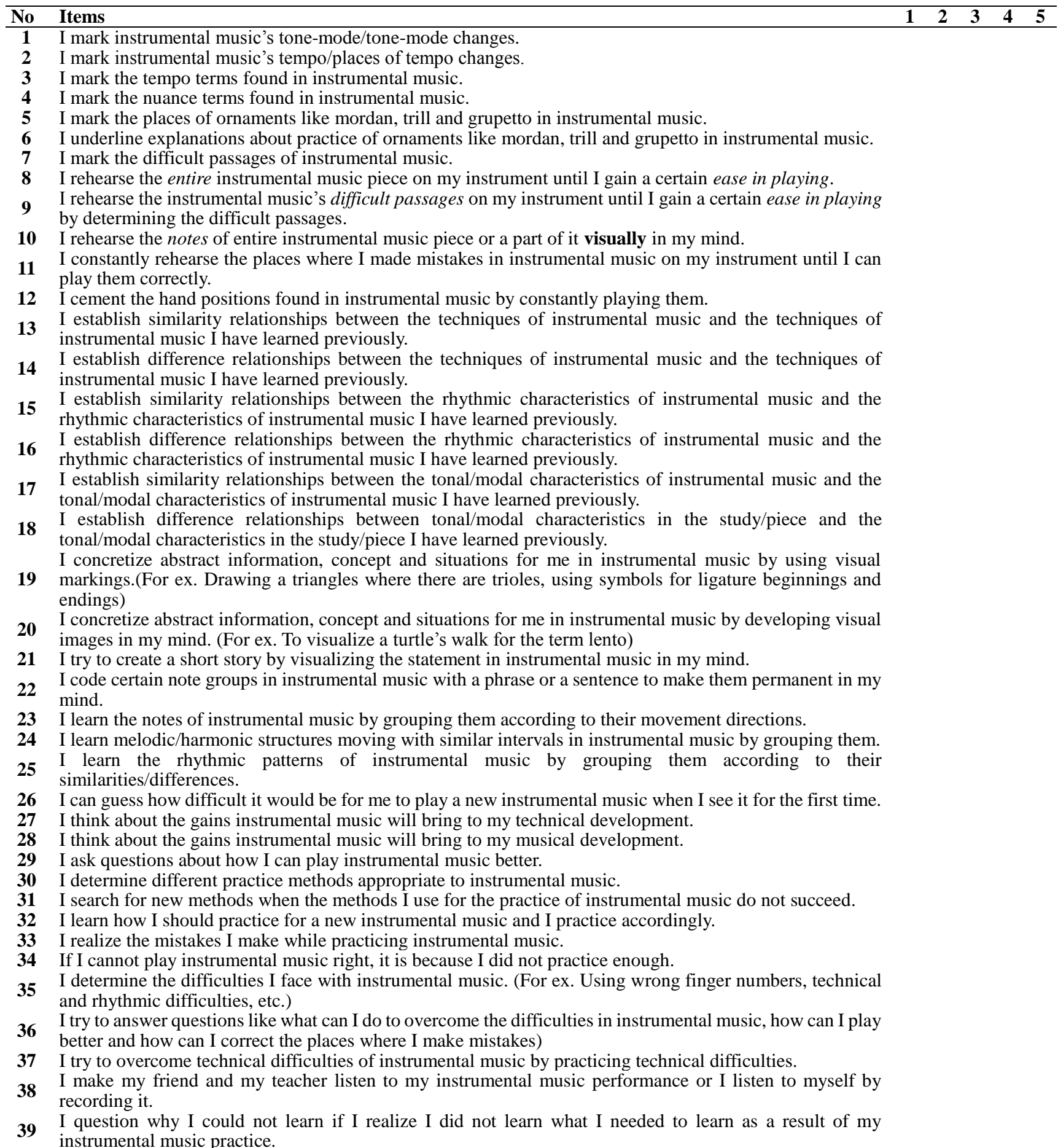

$\begin{array}{llllll}* \text { Attention Strategies: 1-7; } & * * \text { Rehearsal } & \text { Strategies: } & 8-12 ; & * * * \text { Elaboration } & \text { Strategies: } \\ * * * * \text { Articulation-Organization: } 19-25 ; * * * * \text { Comprehension Monitoring Strategies: } 26-39 . & & \end{array}$

\section{Copyrights}

Copyright for this article is retained by the author(s), with first publication rights granted to the journal.

This is an open-access article distributed under the terms and conditions of the Creative Commons Attribution license which permits unrestricted use, distribution, and reproduction in any medium, provided the original work is properly cited. 